\author{
ANNA PATALON-JURCZYK \\ https://doi.org/10.33995/wu2019.3.5
}

\title{
Umowa ubezpieczenia przedmiotu leasingu jako umowa na cudzy rachunek
}

Rosnqce znaczenie gospodarcze umowy leasingu przełożyło się w ostatnich latach także na ofertę rynku ubezpieczeniowego. Przedmiotem analizy w niniejszym artykule jest w zwiqzku z tym konstrukcja umowy ubezpieczenia przedmiotu leasingu jako umowy na cudzy rachunek. Ta szczególna forma umowy ubezpieczenia stała się w zasadzie nieodłaczonym elementem towarzyszqcym umowie leasingu. Majac na uwadze konstrukcję prawnq umowy leasingu, a także zakres i charakter umowy ubezpieczenia, analizie podano praktyczne problemy zwiqzane z zapewnieniem skutecznej ochrony ubezpieczeniowej przedmiotu leasingu.

Słowa kluczowe: leasing, ubezpieczenie na cudzy rachunek, interes ubezpieczeniowy, umowa ubezpieczenia, korzystajacy, finansujący.

\section{Pojęcie umowy leasingu}

Umowa leasingu ${ }^{1}$ ma swoje źródła już w starożytnym Rzymie, gdzie najem rzeczy [locatio conductio rei) jako umowa dwustronna mógł dotyczyć zarówno rzeczy ruchomej, jak również nieruchomości, i pełnił funkcje współczesnej umowy najmu oraz dzierżawy. Locatio conductio rei poprzez dopuszczalność najmu rzeczy własnej, którą uprzednio sprzedano przyszłemu wynajmującemu, stanowiła prototyp leasingu zwrotnego ${ }^{2}$. Umowa leasingu od roku 2000 jest umową nazwaną regulowana przepisami Kodeksu cywilnego ${ }^{3}$. Przez umowę leasingu zgodnie z art. $709^{1}$ k.c. finansujący

1. Jak wskazuje J. Brol „wyraz «leasing» pochodzący z języka angielskiego (lease), oznacza właśnie najem, dzierżawę. Leasing w ścisłym tego słowa znaczeniu nie jest jednak ani najmem, ani dzierżawą, ani sprzedażą na raty", J. Brol, Umowa leasingu, LexisNexis, Warszawa 2010, s. 18.

2. T. Cicirko, Ogólna charakterystyka transakcji leasingowych, [w:] T. Cicirko, A. Karmańska, P. Russel, Determinanty rozwoju transakcji leasingowych w Polsce, Oficyna Wydawnicza SGH, Warszawa 2014, s. 12 i przywołana tam literatura.

3. TytułXVII ${ }^{1}$ został wprowadzony do Kodeksu cywilnego ustawą z dnia 26 lipca 2000 r. o zmianie ustawy - Kodeks cywilny (Dz. U. $2000 \mathrm{nr}$ 74, poz. 85?). 
zobowiązuje się, w zakresie działalności swego przedsiębiorstwa, nabyć rzecz od oznaczonego zbywcy na warunkach określonych w tej umowie i oddać tę rzecz korzystającemu do używania albo używania i pobierania pożytków przez czas oznaczony. Korzystający natomiast zobowiązuje się zapłacić finansującemu - w uzgodnionych ratach - wynagrodzenie pieniężne, równe co najmniej cenie lub wynagrodzeniu z tytułu nabycia rzeczy przez finansującego.

Charakter prawny umowy leasingu wskazuje, że jest ona umową zbliżoną do umowy najmu, w przypadku oddania przedmiotu leasingu do używania oraz umowy dzierżawy, jeśli korzystający ma prawo do używania i pobierania pożytków. Różnica polega na tym, że umowa leasingu zobowiązuje finansującego do nabycia określonej w umowie rzeczy, która to rzecz w umowie najmu czy dzierżawy przed zawarciem umowy jest już własnością odpowiednio wynajmującego lub wydzierżawiającego ${ }^{4}$. Do esentialia negotii umowy leasingu zalicza się po pierwsze zakup przedmiotu leasingu przez finansującego w uzgodnieniu z korzystającym, po drugie oddanie tego przedmiotu do używania lub używania i pobierania pożytków przez korzystającego, a po trzecie zapłatę finansującemu wynagrodzenia pieniężnego, odpowiadającego co najmniej cenie nabycia rzeczy, przez co umowa leasingu jest umową wzajemna ${ }^{5}$. Najbardziej charakterystyczną cechą leasingu jest utrzymujące się przez cały okres obowiązywania umowy władztwo ekonomiczne korzystającego nad przedmiotem leasingu (to korzystającemu przysługuje prawo wykorzystywania dobra), a władztwo prawne - finansującemu. Umowa leasingu może zawierać także postanowienia dotyczące możliwości wykupu przedmiotu leasingu przez korzystającego na koniec trwania umowy ${ }^{6}$.

\section{Istota umowy ubezpieczenia na cudzy rachunek}

Umowy ubezpieczenia na rzecz osoby trzeciej niewątpliwie należą do dyskusyjnej problematyki ubezpieczeniowej, z uwagi na wątpliwości dotyczące jednoznacznego ustalenia podstawy prawnej funkcjonowania tej umowy? Najczęściej przyjmuje się, że art. 808 k.c. stanowi lex specialis w stosunku do regulacji zawartej w art. 393 k.c. ${ }^{8}$, co w przekonaniu autorki jest najwłaściwszym

4. T. Krywan, Leasing samochodów osobowych, Publikacje Elektroniczne ABC.

5. M. Pannert, Wpływ upadłości likwidacyjnej na wykonywanie zobowiqzań z umów wzajemnych, Wolters Kluwer, Warszawa 2010; Tak również J. Brol, op. cit., s. 58.

6. T. Cicirko, op. cit., s. 1 ?.

7. M. Drzewicki, Ubezpieczenia gospodarcze: przepisy, komentarz: elementarne zagadnienia cywilnoprawne, umowa ubezpieczeń - metodyka, wybrane typy ubezpieczeń, ubezpieczenie na życie, ubezpieczenia emerytalne, ubezpieczenie oszczędnościowe, TUR, Jaktorów 1998, s. 79.

8. M. Bednarek wskazuje, że art. 808 k.c. stanowi „leges speciales w stosunku do ogólnej regulacji zastrzeżenia umownego tego typu zamieszczonej w art. 393 k.c. Zatem do przepisów tego artykułu można sięgnąc dopiero w sprawach nieuregulowanych w przepisach szczególnych". Zob. M. Bednarek, Umowa o świadczenie na rzecz osoby trzeciej (art. 393 k.c.), [w:] System prawa prywatnego. Prawo zobowiqzań - część ogólna. Tom 5, [red.] E. Łętowska, CH Beck, Warszawa 2013, s. 1031 i przywołana tam literatura. Tak również H. Ciepła, Komentarz do art. 808, w: Komentarz do Kodeksu cywilnego. Księga trzecia. Zobowiqzania. Tom 2, [red.] G. Bieniek, LexisNexis, Warszawa 2011, s. 760; G. Karaszewski, Komentarz do art. 393, [w:] Kodeks cywilny. Komentarz, [red.] J. Ciszewski, LexisNexis, Warszawa 2014, s. 665; J. Łopuski, Komentarz do art. 808, [w:] Kodeks cywilny z komentarzem. Tom 2, [red.] J. Winiarz, Wydawnictwo Prawnicze, Warszawa 1989, s. 727; B. Kucharski, Przeniesienie praw z umowy ubezpieczenia, Wolters Kluwer, Warszawa 2010, s. 177-178; Z. Długosz, Ograniczenia swobody umów w ksztaltowaniu stosunku ubezpieczenia na cudzy rachunek, Wolters Kluwer, Warszawa 2017, s. 112-113. 
sposobem określenia relacji pomiędzy tymi przepisami. Jednocześnie „artykuł 808 k.c. stanowi lex specialis w stosunku do art. 393 k.c. w takim zakresie, w jakim dopuszcza zawarcie umowy ubezpieczenia na rzecz osoby nieoznaczonej. W pozostałym zakresie uregulowanie art. 808 k.c. nie odbiega od zasad określonych w art. 393 k.c. W związku z tym umowy na rzecz osoby trzeciej nie domniemywa się"9 . Umowę ubezpieczenia na cudzy rachunek można uznać za kwalifikowaną umowę ubezpieczenia na rzecz osoby trzeciej ${ }^{10}$.

Należy wyraźnie podkreślić, że „obie formy umowy na rzecz osoby trzeciej tak dalece różnią się konstrukcyjnie, jak również w swoich skutkach, że nie sposób ujmować ich łącznie"11. Zasadnicza różnica pomiędzy umową ubezpieczenia na rzecz osoby trzeciej a umową na cudzy rachunek to ubezpieczany interes ubezpieczeniowy. W przypadku umowy ubezpieczenia na cudzy rachunek ubezpieczający nie ubezpiecza swojego interesu majątkowego lub niemajątkowego, natomiast w przypadku ubezpieczenia na rzecz osoby trzeciej sensu stricte ubezpieczający ubezpiecza własny interes majątkowy, wprowadzając do umowy jedynie zastrzeżenie świadczenia na rzecz trzeciego w razie zajścia wypadku ${ }^{12}$. Dlatego też źródeł ubezpieczenia na rzecz osoby trzeciej należy upatrywać w ogólnie rozumianej „przezorności ojca rodziny, a ubezpieczenie na cudzy rachunek rozwinęło się na gruncie stosunków wynikających z obrotu handlowego oraz stosunków między pracodawcami a pracownikami w związku z odpowiedzialnością pracodawców za skutki wypadków przy pracy"13.

W umowie ubezpieczenia na rzecz osoby trzeciej sensu stricte ubezpieczający obejmuje zawieraną umową własny interes majatkowy lub własne życie, wskazując osobę uprawniona do otrzymania odszkodowania lub świadczenia ${ }^{14}$. Wskazanie uposażonego nie musi być imienne - dopuszczalne jest zawarcie umowy ubezpieczenia na okaziciela ${ }^{15}$, albowiem w umowie o świadczenie na rzecz osoby trzeciej najważniejsze jest wypełnienie kryterium oznaczalności

9. W. Dubis, Komentarz do art. 808, [w:] Kodeks cywilny. Komentarz, [red.] E. Gniewek, P. Machnikowski, CH Beck, Warszawa 2016, s. 1488.

10. M. Fras, Umowa ubezpieczenia na cudzy rachunek w kontekście ustawy o działalności ubezpieczeniowej i reasekuracyjnej, [w:] Zagadnienia prawne i ekonomiczne dotyczqce umów ubezpieczeń na życie, [red.] M. Szczepańska, Wolters Kluwer, Warszawa 2017.

11. A. Wassiewicz, E. Kowalewski, Postulowany kształt umowy ubezpieczenia w kodeksie cywilnym, „Państwo i Prawo" 1993 z. 11-12, s. 10; Tak również E. Kowalewski, Reforma polskiego prawa ubezpieczeń gospodarczych w latach 1990-2001, [w: Ubezpieczenia w gospodarce rynkowej. Tom 4, [red.] T. Sangowski, Oficyna Wydawnicza Branta, Bydgoszcz-Poznań 2002, s. 23-24.

12. J. Pokrzywniak, Komentarz do art. 808, [w:] M. Orlicki, J. Pokrzywniak, Umowa ubezpieczenia. Komentarz do nowelizacji kodeksu cywilnego, Wolters Kluwer, Warszawa 2008, s. 40; Sąd Najwyższy także dokonuje podziału umów uregulowanych wart. $808 \S 1$ k.c. na umowy ubezpieczenia na rzecz osoby trzeciej sensu stricto oraz umowy ubezpieczenia na cudzy rachunek - Wyrok Sądu Najwyższego z dnia 25 stycznia 2000 r. I CKN 331/98, LEX nr 5680 ?

13. J. Łazowski, Wstęp do nauki o ubezpieczeniach, Wydawnictwo Prawnicze LEX, Sopot 1998, s. 132; Tak również M. Fras, Umowa ubezpieczenia na cudzy...

14. A. Chróścicki, Umowa ubezpieczenia po nowelizacji kodeksu cywilnego. Komentarz, Wolters Kluwer, Warszawa 2008, s. 34.

15. Wyrok Sądu Najwyższego z dnia 7 października 1971 r. III CRN 255/71, LEX nr 1329; Tak również A. Wạsiewicz, Z rozważań nad funkcjonowaniem przepisów kodeksu cywilnego normujacych umowę ubezpieczenia, [w:] Rozprawy z prawa cywilnego: księga pamiqtkowa ku czci Witolda Czachórskiego, [red.] J. Rajski, PWN, Warszawa 1985, s. 345. 
osoby trzeciej ${ }^{16}$. W umowie na cudzy rachunek ubezpieczajacy, działając we własnym imieniu, obejmuje ochroną ubezpieczeniową cudzy interes majątkowy, co powoduje, że ubezpieczający i ubezpieczony nie jest tym samym podmiotem ${ }^{17}$. Ubezpieczający może także w ramach jednej umowy zabezpieczyć zarówno swój własny interes ubezpieczeniowy, jak i cudzy interes majątkowy, w szczególności interes członków swojej rodziny. Jednocześnie, zgodnie ze stanowiskiem Sądu Najwyższego, ubezpieczony ma prawo żądać świadczenia od zakładu ubezpieczeń tylko wówczas gdy ubezpieczający wyraźnie zastrzegł, że w razie zajścia przewidzianego w umowie wypadku ubezpieczyciel ma obowiązek świadczenia do rąk - niekoniecznie imiennie tam wskazanego - ubezpieczonego, który poniósł szkodę ${ }^{18}$.

Kauzą zawarcia umowy ubezpieczenia na cudzy rachunek jest więc stosunek łączący ubezpieczającego i ubezpieczonego. Stosunkiem takim może być: 1) zamiar obdarowania ubezpieczonego ochroną ubezpieczeniowa; 2) chęć uzyskania wzajemnego przysporzenia (causa obligandi), gdzie w zamian za objęcie ochroną ubezpieczeniową ubezpieczonego, ubezpieczający będzie otrzymywał przysporzenie; 3] zamiar wykonania zobowiązania zaciągniętego uprzednio pomiędzy ubezpieczającym a ubezpieczonym (causa solvendi), przy czym jeżeli wykonanie tego zobowiązania ma być skuteczne, to jego przedmiotem powinno być zobowiązanie do objęcia ochroną ubezpieczeniową ubezpieczonego, gdyż to on otrzyma świadczenie w postaci ochrony ubezpieczeniowej ${ }^{19}$. W ubezpieczeniach majątkowych - z uwagi na przedmiot ubezpieczenia - jedyna dopuszczalna forma umowy na rzecz osoby trzeciej jest właśnie umowa na cudzy rachunek ${ }^{20}$. Umowa ubezpieczenia odpowiedzialności cywilnej, gdzie mamy do czynienia z wypłatą świadczenia osobie trzeciej, również może być zawarta na cudzy rachunek. Natomiast cele, jakie spełnia ubezpieczenie odpowiedzialności cywilnej, są odmienne od przeznaczenia umowy na rzecz osoby trzeciej. Istota ubezpieczenia odpowiedzialności cywilnej nie jest bowiem zapewnienie ochrony ubezpieczeniowej osobie trzeciej, chociaż to ona otrzymuje świadczenie, natomiast to nie na jej rzecz zawierana jest umowa ubezpieczenia i nie jej interes ubezpieczeniowy jest obejmowany ochroną ${ }^{21}$.

\section{Interes ubezpieczeniowy}

Interes ubezpieczeniowy to taki stosunek do przedmiotu ubezpieczenia, który w razie materializacji ryzyka może być dotknięty szkoda, co można określić jako „zainteresowanie w bezpieczeństwie rzeczy". Interes ubezpieczeniowy zawsze musi być analizowany w odniesieniu do podmiotu, który ma korzystać z ochrony ubezpieczeniowej. Jednocześnie w stosunku do tego samego przedmiotu

16. M. Bednarek, op. cit., s. 1053; Tak również P. Machnikowski, Komentarz do art. 393, [w:] Kodeks cywilny. Komentarz, [red.] E. Gniewek, P. Machnikowski, CH Beck, Warszawa 2016, s. 741.

17. A. Chróścicki, op. cit., s. 34.

18. Wyrok Sądu Najwyższego z dnia 4 października 1984 r. Il CR 329/84, LEX nr 8628.

19. Z. Długosz, op. cit., s. 143-145.

20. M. Orlicki, Projektowane zmiany w regulacji materialnoprawnej umowy ubezpieczenia, w: Umowa ubezpieczenia. Aktualne problemy prawne. Materiały z Konferencji Naukowej „Problemy nowelizacji przepisów o umowie ubezpieczenia z dnia 2 marca 2005 r.”, pod red. A. Kocha, Bydgoszcz - Poznań 2005, s. 28.

21. Z. Szymański, Ogólna charakterystyka ubezpieczenia od odpowiedzialności cywilnej, „Wiadomości Ubezpieczeniowe", 1964 nr 2, s. 6. 
może być wiele podmiotów, które mają interes dotyczący właśnie tego dobra ${ }^{22}$. Szkodajest negacja istnienia zaspokojonego interesu ubezpieczeniowego wskutek materializacji ryzyka oraz negacja wzbogacenia się z tytułu zawartej umowy ubezpieczenia ${ }^{23}$. Ryzyko ściśle koreluje z interesem ubezpieczeniowym, gdyż w zależności od rodzaju ubezpieczenia realizuje się wobec różnych wartości, które ubezpieczony chce objąć ochroną ubezpieczeniową ${ }^{24}$. Interes ubezpieczeniowy odróżnia umowę ubezpieczenia od zakładów czy gier losowych, które także opierają się na ryzyku, gdyż jego istnienie ma prowadzić nie do wzbogacenia się, a jedynie do pokrycia powstałej szkody 25 .

Interes ubezpieczeniowy określany jest jako „rodzaj ekonomicznego interesu”, posiadanego przez jednostkę, uprawniającego ją do otrzymania świadczenia przewidzianego w umowie. Jednostka tylko wtedy będzie miała interes ubezpieczeniowy, jeśli zajście określonego wypadku może spowodować stratę finansową lub szkodę osobistą ${ }^{26}$. Mariusz Fras natomiast wskazuje, że „«interes ubezpieczeniowy» rozumieć należy jako stosunek, dzięki któremu ubezpieczony - może ponieść szkodę"2?. Dokonując podziału interesu ubezpieczeniowego, można wyróżnić subiektywny i obiektywny interes ubezpieczeniowy. Pierwszy przypadek ogranicza się jedynie do interesu osoby, na rzecz której została zawarta umowa, a w drugim przypadku oprócz osoby wskazanej w umowie chroniony jest interes innych osób (np. zastawnika lub przewoźnika). Przy czym dominujące wśród zakładów ubezpieczeń jest postrzeganie interesu ubezpieczeniowego w aspekcie subiektywnym ${ }^{28}$. Interes ubezpieczeniowy z jednej strony warunkuje ważność umowy ubezpieczenia, z drugiej zaś - służy do analizowania przedmiotu ubezpieczenia ${ }^{29}$. Za pośrednictwem interesu ubezpieczeniowego są zakreślane granice swobody zawarcia umowy ubezpieczenia ${ }^{30}$.

Jednocześnie „interes ubezpieczeniowy, postrzegany jako przedmiot ubezpieczenia zagrożony ryzykiem, determinuje zachowanie stron omawianego stosunku w postaci deklaracji ryzyka, ceny przyjęcia tego ryzyka przez ubezpieczyciela oraz zobowiązanie tego ostatniego do świadczenia na wypadek wystapienia wypadku ubezpieczeniowego, a ze strony ubezpieczającego zapłaty

22. D. Maśniak, Interes ubezpieczeniowy, niepub., szerzej: D. Fuchs, Doniosłość prawna art. 812 KC w: Księga Jubileuszowa Profesora Eugeniusz Kowalewskiego, Toruń 2019 s. 99 i nn.

23. K. Malinowska, Komentarz do art. 821, [w:] Prawo ubezpieczeń gospodarczych. Komentarz. Tom II. Prawo o kontraktach w ubezpieczeniach. Komentarz do przepisów i wybranych wzorców umów, [red.] Z. Brodecki, M. Glicz, M. Serwach, Wolters Kluwer, Warszawa 2010; Tak również K. Malinowska, Umowa ubezpieczenia w Europie bez granic, Oficyna Wydawnicza Branta, Bydgoszcz-Warszawa 2008, s. 214.

24. R. Stefanicki, Interes ubezpieczeniowy w świetle art. 821 Kodeksu cywilnego, [w:] Kierunki rozwoju ubezpieczeń gospodarczych w Polsce. Wybrane zagadnienia prawne, [red.] B. Gnela, M. Szaraniec, Difin, Warszawa 2013, s. 19.

25. E. Kowalewski, Wprowadzenie do teorii interesu ubezpieczeniowego, [w:] Ubezpieczenia w gospodarce rynkowej. Tom 3, [red.] A. Wąsiewicza, Oficyna Wydawnicza Branta, Bydgoszcz 1997, s. 74; Tak również K. Malinowska, Komentarz...

26. B. Hadyniak, Ubezpieczenie jako urzqdzenie finansowe, [w:] Ubezpieczenia. Podręcznik akademicki, [red.] J. Handschke, J. Monkiewicz, Poltext, Warszawa 2010, s. 52.

27. M. Fras, Umowa ubezpieczenia grupowego. Aspekty prawne, Wolters Kluwer, Warszawa 2015, s. 393.

28. W.W. Mogilski, Umowa ubezpieczenia na rzecz osoby trzeciej, [w:] Ubezpieczenia w gospodarce rynkowej. Tom 1, [red.] A. Wasiewicz, Oficyna Wydawnicza Branta, Bydgoszcz 1994, s. 96-97.

29. K. Malinowska, Umowa...

30. A.M. Kubiak, Interes ubezpieczeniowy w umowie ubezpieczenia na cudzy rachunek i na rzecz osoby trzeciej, „Prawo Asekuracyjne” 2012, nr 4, s. 67; Tak również. K. Malinowska, Umowa ..., s. 107. 
składki ubezpieczeniowej" ${ }^{31}$. W związku z różnymi potencjalnymi układami podmiotowymi w doktrynie wyróżnia się kilka rodzajów interesu ubezpieczeniowego:

1) interes sukcesywny, przysługujący podmiotom w określonych sekwencjach czasowych, interes przechodzi z jednej osoby na druga;

2) interesy alternatywne, występują w przypadku kiedy interesy dwóch lub więcej podmiotów wzajemnie się wykluczają, co może się zdarzyć np. w sytuacji sporu co do własności danej rzeczy, w okresie do rozstrzygnięcia tego sporu;

3) interesy konkurujące, kiedy istnienie interesu ubezpieczeniowego jednego podmiotu ma bezpośredni wpływ na interes ubezpieczeniowy drugiego podmiotu (pomniejsza go);

4) interesy koincydujące, powstaja w sytuacji kiedy uszczerbek w interesie jednego podmiotu może powodować uszczuplenie interesu drugiego podmiotu, czego przykładem jest ubezpieczenie odpowiedzialności cywilnej, gdzie ubezpieczony zabezpiecza swój interes majątkowy, chroniąc także interes poszkodowanej osoby trzeciej ${ }^{32}$.

Maksymalny poziom ochrony ubezpieczeniowej jest limitowany, a jego granicę wyznacza tzw. majątkowa wartość interesu osoby ubezpieczonej. Wówczas z jednej strony szkoda jest umniejszeniem lub unicestwieniem interesu, a z drugiej strony brak interesu nie doprowadzi do powstania szkody ${ }^{33}$. Interes ubezpieczeniowy jest traktowany jako kryterium oceny wysokości świadczenia ubezpieczeniowego, które może dynamicznie zmieniać się w okresie ubezpieczenia ${ }^{34}$. Istnieje możliwość objęcia ubezpieczeniem przedmiotów niebędących własnością ubezpieczonego, przy czym istotna jest wówczas dobra wiara ubezpieczonego, co bezpośrednio wiąże się z istnieniem interesu do ubezpieczenia posiadanego mienia ${ }^{35}$. Konieczne jest tym samym, aby ubezpieczony byłzainteresowany poszukiwaniem ochrony ubezpieczeniowej w granicach interesu ubezpieczeniowego ${ }^{36}$.

Interes ubezpieczeniowy jest definiowany jako stosunek, w ramach którego określony podmiot na skutek przewidzianego w umowie wypadku może ponieść szkodę. Stosunek ten odnosi się zarówno do rzeczy, zdarzeń jak też czyjegoś zachowania się, a szkoda jest zmiana niezgodna z wolą zainteresowanego podmiotu ${ }^{37}$. Jest to ścisły układ podmiotowy, w którym kluczowe jest określenie, w jakim stopniu zawierana umowa ubezpieczenia pokrywa się z potrzebami ubezpieczonego, czyli jego interesem ubezpieczeniowym. Podstawowy cel ubezpieczeń, którym jest zrekompensowanie szkody powstałej na skutek zajścia wypadku, jest możliwy do realizacji dopiero po rozstrzygnięciu, kto ma interes w zapewnieniu ochrony ubezpieczeniowej określonego dobra (interes otrzymania świadczenia ubezpieczeniowego) ${ }^{38}$.

Pojęcie interesu ubezpieczeniowego należy odróżnić od pojęcia interesu majątkowego, odnoszạcego się jedynie do ubezpieczeń majątkowych oraz określającego, co może być przedmiotem

31. R. Stefanicki, op. cit., s. 20.

32. E. Kowalewski, Wprowadzenie ..., s. 79 - 81; Tak również A.M. Kubiak, op. cit., s. 70.

33. A.M. Kubiak, Interes ..., s. 74.

34. K. Malinowska, Umowa ..., s. 219.

35. K. Malinowska, Komentarz...

36. Ibidem.

37. K. Malinowska, Umowa ..., s. 214-215.

38. G. Pinker, Interes ubezpieczeniowy w ubezpieczeniach morskich na rynku angielskim, „Prawo Asekuracyjne” 1999, nr 2, s. 33. 
ubezpieczenia. Interes majątkowy mieści się w zakresie pojęcia interesu ubezpieczeniowego, nie można jednak używać tych dwóch pojęć jako synonimów.

$W$ relacji pomiędzy ubezpieczającym a ubezpieczonym istotne są przesłanki zawierania umowy przez ubezpieczającego, która chroni interes ubezpieczeniowy innej osoby. Marcin Orlicki wskazuje dwie zasadnicze przesłanki, które skłaniają ubezpieczającego do zawarcia umowy ubezpieczenia majątkowego na cudzy rachunek. Mianowicie ubezpieczającemu może zależeć na zachowaniu w niepogorszonym stanie i bez uszczerbku na wartości interesu majątkowego osoby trzeciej albo łączący ubezpieczającego z ubezpieczonym stosunek pozaubezpieczeniowy powoduje powstanie po stronie ubezpieczającego zobowiązania do dbałości o ten interes ${ }^{39}$. Zasadniczo nie jest to istotne dla zakładu ubezpieczeń, z którym została zawarta przedmiotowa umowa ubezpieczenie. $Z$ reguły pomiędzy ubezpieczającym a osobą trzecią, przyszłym ubezpieczonym, istnieje inny stosunek prawny, z którego wynika obowiązek zawarcia określonej umowy przez ubezpieczającego ${ }^{40}$.

\section{Zobowiązanie korzystającego do zawarcia umowy ubezpieczenia}

W Kodeksie cywilnym nie ma uregulowanego obowiązku ubezpieczenia przedmiotu leasingu, kwestię tę pozostawia się do ustalenia stronom. W praktyce obowiązek zawarcia umowy ubezpieczenia zazwyczaj jest zastrzegany przez finansującego w umowie leasingu wraz z określeniem dokładnego zakresu ochrony ubezpieczeniowej, jaki przedmiotowa umowa powinna obejmować ${ }^{41}$. Regulowanie takiego obowiązku przez finansującego w umowie leasingu jest ściśle związane z obowiązkami korzystającego wynikającymi z istoty zawartej umowy oraz bezpośrednim zabezpieczeniem interesów majątkowych finansującego. Poprzez taką konstrukcję dochodzi do zawarcia umowy na cudzy rachunek, która w istocie zabezpiecza zarówno interesy ubezpieczającego, jak i ubezpieczonego.

Mając na uwadze, że przedmiotem umowy leasingu zdefiniowanej w Kodeksie cywilnym mogą być wyłącznie rzeczy, umowa ubezpieczenia przedmiotu leasingu zawsze będzie umowa ubezpieczenia majątkowego. Tym samym ochroną ubezpieczeniową będzie obejmowany interes majątkowy właściciela rzeczy, czyli finansującego. Korzystający, który będzie zawierał umowę ubezpieczenia związaną z ochrona przedmiotu leasingu przed utratą lub zniszczeniem, zawiera umowę ubezpieczenia na rachunek finansującego, zabezpieczając także swój interes związany z obowiązkiem pieczy nad przedmiotem leasingu i dbania o jego funkcjonalną i ekonomiczna przydatność. Nie jest to więc klasyczna forma umowy ubezpieczenia na cudzy rachunek, gdyż interes w jej zawarciu ma także ubezpieczający (korzystający), który jest wyłącznie posiadaczem rzeczy.

W drodze swobody umów pomiędzy finansującym i korzystającym jest ustalany obowiązek ubezpieczenia przedmiotu leasingu i ponoszenia ciężaru składki ubezpieczeniowej. Jest to specyficzna konstrukcja, w której podmiot mający interes ubezpieczeniowy nie zawiera samodzielnie

39. M. Orlicki, Strony umowy ubezpieczenia i podmioty zwiqzane ze stosunkiem prawnym ubezpieczenia, [w:] System prawa prywatnego. Prawo zobowiqzań - część szczegółowa. Tom 8, [red.] J. Panowicz-Lipska, CH Beck, Warszawa 2011, s. 831.

40. M. Drzewicki, op. cit., s. 81.

41. K. Kopaczyńska-Pieczniak, Komentarz do art. 7096, [w:] Kodeks cywilny. Komentarz. Tom 3. Zobowiqzania - część szczególna, [red.] A. Kidyba, LEX 2014. 
umowy ubezpieczenia, a zobowiązuje do tego inny podmiot, zazwyczaj określając szczegółowo rodzaj oraz zakres umowy ubezpieczenia, a nawet sumę ubezpieczenia czy inne szczególne warunki związane z późniejszym wykonywaniem umowy ubezpieczenia ${ }^{42}$. Celem takiej umowy ubezpieczenia jest bezsprzecznie zabezpieczenie interesu majątkowego finansujaccego, jak również wyeliminowanie lub ograniczenie negatywnych skutków uszkodzenia lub utraty przedmiotu leasingu, a zatem materializacji ryzyk w stosunku do korzystającego (art. $709^{11}$ k.c.). Korzystający, który nie wypełni ciążącego na nim obowiązku pieczy nad przedmiotem leasingu i dbania o jego funkcjonalną i ekonomiczną przydatność, naraża się na możliwość wypowiedzenia umowy leasingu przez finansującego. Natomiast jeśli przedmiot leasingu zostanie utracony, wówczas umowa wygasa z mocy prawa, co bezpośrednio wiąże się z koniecznością uregulowania niezapłaconych rat wynagrodzenia oraz obowiązkiem naprawienia szkody finansującemu (art. $709^{5} \S 3$ k.c.). Kwestią wtórą w tej sytuacji będzie uniemożliwienie korzystającemu faktycznego używania lub używania i pobierania pożytków z przedmiotu leasingu.

Zgodnie z dyspozycja art. $709^{6}$ k.c., jeżeli w umowie leasingu zastrzeżono, że korzystający obowiązany jest ponosić koszty ubezpieczenia rzeczy od jej utraty w czasie trwania umowy leasingu, w braku odmiennego postanowienia umownego, koszty te obejmują składkę z tytułu ubezpieczenia na ogólnie przyjętych warunkach. Obowiązek ponoszenia kosztów ubezpieczenia nie jest tożsamy z obowiązkiem zawarcia umowy ubezpieczenia, pomimo że w praktyce nierozdzielnie obowiązki te nakładane są na korzystającego. Kosztami składki ubezpieczeniowej korzystający może być obciążony także w przypadku zawarcia umowy ubezpieczenia przez finansującego, który przenosi ciężar ponoszenia kosztów składki w umowie leasingu, uwzględniając go w rozliczeniu z korzystającym. Dyspozycja art. $709^{6}$ k.c. ma jednak wąski zakres zastosowania i odnosi się wyłącznie do przypadków ubezpieczenia rzeczy od utraty w czasie trwania umowy leasingu, nie dotyczy więc innych ubezpieczeń majątkowych ${ }^{43}$. Należy również podkreślić, że zawarcie umowy ubezpieczenia jest czynnością dyspozytywna, gdyż strony umowy leasingu mogą w odmienny sposób uregulować zapewnienie ochrony majątkowej nad przedmiotem leasingu.

\section{Formy ubezpieczenia przedmiotu leasingu}

Ubezpieczenie przedmiotu leasingu może przybrać cztery zasadnicze formy:

- zawarcie umowy ubezpieczenia przez finansującego, który w pełni pokrywa koszty składki;

- zawarcie umowy ubezpieczenia przez finansującego, przy czym kosztami składki obciążony jest korzystający, co zostaje uwzględnione w rozliczeniu pomiędzy stronami umowy leasingu. W tych okolicznościach koszt składki ubezpieczeniowej ponoszony przez korzystającego nie stanowi wynagrodzenia z tytułu umowy leasingu, a jest dodatkowym zobowiązaniem do zwrotu kosztów ${ }^{44}$;

42. Ibidem.

43. Ibidem.

44. Zob. wyrok Trybunału Sprawiedliwości Unii Europejskiej z 17 stycznia 2013 r. w sprawie C-224/11 mającej za przedmiot wniosek o wydanie, na podstawie art. 26? TFUE, orzeczenia w trybie prejudycjalnym, złożony przez Naczelny Sąd Administracyjny (Polska) postanowieniem z dnia $?$ kwietnia 2011 r., które wpłynęło do Trybunału w dniu 13 maja 2011 r., w postępowaniu: BGŻ Leasing sp. z o.o. przeciwko Dyrektorowi Izby Skarbowej w Warszawie (http://curia.europa.eu). 
- zawarcie umowy ubezpieczenia przez korzystającego, gdzie koszt składki ubezpieczeniowej obciąża finansującego;

- zawarcie umowy i jednocześnie pokrycie kosztów składki przez korzystającego ${ }^{45}$.

Jeśli zobowiązanie do opłacania składki ubezpieczeniowej przez korzystającego nie zostanie zastrzeżone w umowie leasingu, wówczas zastosowanie znajdą ogólnie przyjęte warunki. Przekłada się to na obowiązek opłacenia składki przez korzystającego bądź zwrotu jej wartości finansującemu w wysokości ogólnie przyjętej w umowach ubezpieczenia danego rodzaju ${ }^{46}$. Mając na uwadze tak niejednoznaczne uregulowanie i wykładnię przepisu w tym zakresie, trudno określić wysokość takiej składki, szczególnie przy obecnej polityce cenowej na rynku ubezpieczeń.

Ta daleko idąca swoboda w kształtowaniu stosunku prawnego w umowie leasingu ${ }^{47}$ oraz silniejsza ekonomicznie pozycja finansującego narażają korzystającego na przyjmowanie na siebie nadmiernych obciążeń związanych z umową ubezpieczenia. Niejednokrotnie wymagany przez leasingodawcę zakres ubezpieczenia jest na tyle szeroki, że korzystający ma trudności w dopasowaniu oferty ubezpieczenia, co w konsekwencji ma skłaniać go do zawierania umów ubezpieczenia za pośrednictwem finansującego. Częstą praktyką stosowaną przez finansujących jest obowiązek przedłożenia przez korzystającego przed zawarciem umowy oferty ubezpieczenia z wymaganiami stawianymi przez finansującego. W takiej sytuacji dopiero po zatwierdzeniu przedstawionej oferty korzystający jest uprawniony do zawarcia umowy ubezpieczenia. Taka praktyka jest z jednej strony wyrazem dbałości finansującego o przedmiot leasingu, a z drugiej jest przede wszystkim kolejnym z mechanizmów mających zachęcić do skorzystania z oferty za pośrednictwem finansującego, co jest znacznie mniej sformalizowane. Zazwyczaj korzystający ma ściśle określony termin na zawarcie umowy ubezpieczenia ${ }^{48}$, co również może być czynnikiem ograniczającym mu możliwości szukania adekwatnej oferty.

Należy zaznaczyć, że często wybranie przez korzystającego umowy ubezpieczenia sugerowanej przez finansujaccego może oznaczać konieczność ponoszenia wyższych kosztów składki ubezpieczeniowej. W interesie ekonomicznym korzystającego będzie więc znalezienie oferty ubezpieczenia zgodnej z oczekiwaniami finansujacego, ale adekwatnej także do wymagań korzystającego w zakresie wysokości składki. Ponadto finansujący nie gwarantuje stałej składki ubezpieczeniowej przez cały okres trwania umowy leasingu, dlatego istotne dla korzystającego powinno być zapewnienie sobie możliwości zawarcia umowy ubezpieczenia spośród ofert dostępnych na rynku. Korzystający, który w umowie leasingu przez cały okres jej trwania zadeklaruje wybór umowy ubezpieczenia sugerowanej przez finansującego, zamyka sobie możliwość zmiany i dostosowania oferty do własnych możliwości ekonomicznych. Finansujący dba o zabezpieczenie swojego interesu ubezpieczeniowego, natomiast wysokość składki jest dla niego kwestią wtórną, gdyż obowiązek jej opłacania przenosi na korzystającego.

W zakresie odszkodowania przysługującego z zawartej umowy ubezpieczenia z reguły uprawnionym do świadczenia od zakładu ubezpieczeń jest finansujący, który w przypadku otrzymania świadczenia przewyższającego jego należność dokonuje rozliczenia z korzystającym. Na korzystającym

45. T. Cicirko, P. Russel, Cywilnoprawna charakterystyka umowy leasingu, [w:] T. Cicirko, A. Karmańska, P. Russel, Determinanty rozwoju transakcji leasingowych w Polsce, Oficyna Wydawnicza SGH, Warszawa 2014, s. 61-62.

46. P. Nazaruk, Komentarz do art. 7096 , w: Kodeks cywilny. Komentarz, [red.] J. Ciszewski, LexisNexis, Warszawa 2014.

47. J. Brol, op. cit., s. 106-10?.

48. Z. Biskupski, Leasing w praktyce, Wydawnictwo Wiedza i Praktyka, Warszawa 2014, s. 46. 
ciąży zazwyczaj obowiązek niezwłocznego poinformowania zakładu ubezpieczeń, a równocześnie także finansującego, o zajściu wypadku. W związku z tym na etapie likwidacji zgłoszonej szkody mamy do czynienia z trójpodmiotowym stosunkiem, gdzie podmioty te muszą ze sobą ściśle współpracować w ramach całej procedury obsługi roszczenia. Nie jest wykluczona sytuacja, w której finansujący zleca dochodzenie roszczeń korzystającemu, natomiast takie sytuacje będą miały miejsce częściej przy mniejszych uszkodzeniach niż przy całkowitej utracie przedmiotu leasingu ${ }^{49}$.

\section{Podsumowanie}

Przedmiotem umowy leasingu zdefiniowanej w Kodeksie cywilnym mogą być wyłącznie rzeczy, dlatego umowa ubezpieczenia przedmiotu leasingu zawsze będzie umową ubezpieczenia majątkowego. Umowa taka istotnie ogranicza konsekwencje związane z utratą rzeczy i w następstwie - z koniecznością rozliczeń związanych z wygaśnięciem umowy leasingu, co leży w interesie obu stron umowy. Z perspektywy korzystającego równowartość odszkodowania z umowy ubezpieczenia zmniejsza albo zupełnie eliminuje obowiązek uregulowania niezapłaconych rat, natomiast z perspektywy finansującego jest to zabezpieczenie na wypadek niewypłacalności korzystajacego w przypadku utraty rzeczy ${ }^{50}$. Z tego względu zawarta umowa ubezpieczenia, będzie łączyła w sobie zarówno ochronę interesów korzystającego, jak również finansującego, co przeczy klasycznej formule umowy na cudzy rachunek, gdzie ochroną ubezpieczeniową powinien być objęty wyłącznie interes ubezpieczonego. Pomimo zabezpieczania interesów dwóch stron umowy leasingu taka umowa ubezpieczenia będzie umową zawartą na rachunek finansującego, który jako właściciel przedmiotu leasingu ma interes majatkowych, który jest przedmiotem ubezpieczenia. W tych okolicznościach należy przyjąć, że jest to naturalna ewolucja umowy ubezpieczenia na cudzy rachunek, która w swej ogólnej formule znalazła nowe zastosowanie przy umowie leasingu.

\section{Wykaz źródeł}

Bednarek M., Umowa o świadczenie na rzecz osoby trzeciej (art. 393 k.c.), [w:] System prawa prywatnego. Prawo zobowiqzań - część ogólna. Tom 5, Łętowska E. [red.], CH Beck, Warszawa 2013. Biskupski Z., Leasing w praktyce, Wydawnictwo Wiedza i Praktyka, Warszawa 2014.

Brol J., Umowa leasingu, LexisNexis, Warszawa 2010.

Chróścicki A., Umowa ubezpieczenia po nowelizacji kodeksu cywilnego. Komentarz, Wolters Kluwer, Warszawa 2008.

Cicirko T., Ogólna charakterystyka transakcji leasingowych, [w:] Cicirko T., Karmańska A., Russel P., Determinanty rozwoju transakcji leasingowych w Polsce, Oficyna Wydawnicza Szkoła Główna Handlowa, Warszawa 2014.

Cicirko T., Russel P., Cywilnoprawna charakterystyka umowy leasingu, [w: ] Cicirko T., Karmańska A., Russel P., Determinanty rozwoju transakcji leasingowych w Polsce, Oficyna Wydawnicza Szkoła Główna Handlowa, Warszawa 2014.

49. Ibidem, s. 35,47 i 5 ?

50. P. Nazaruk, op. cit. 
Ciepła H., Komentarz do art. 808, [w: Komentarz do Kodeksu cywilnego. Księga trzecia. Zobowiqzania. Tom 2, Bieniek G. [red.], LexisNexis, Warszawa 2011.

Długosz Z., Ograniczenia swobody umów w kształtowaniu stosunku ubezpieczenia na cudzy rachunek, Wolters Kluwer, Warszawa 201 ?

Drzewicki M., Ubezpieczenia gospodarcze: przepisy, komentarz: elementarne zagadnienia cywilnoprawne, umowa ubezpieczeń - metodyka, wybrane typy ubezpieczeń, ubezpieczenie na życie, ubezpieczenia emerytalne, ubezpieczenie oszczędnościowe, TUR, Jaktorów 1998.

Dubis W., Komentarz do art. 808, [w:] Kodeks cywilny. Komentarz, Gniewek E., Machnikowski P. [red.], CH Beck, Warszawa 2016.

Karaszewski G., Komentarz do art. 393, [w:] Kodeks cywilny. Komentarz, Ciszewski J. [red.], LexisNexis, Warszawa 2014.

Fras M., Umowa ubezpieczenia grupowego. Aspekty prawne, Wolters Kluwer, Warszawa 2015.

Fras M., Umowa ubezpieczenia na cudzy rachunek w kontekście ustawy o działalności ubezpieczeniowej i reasekuracyjnej, [w:] Zagadnienia prawne i ekonomiczne dotyczqce umów ubezpieczeń na życie, Szczepańska M. [red.], Wolters Kluwer, Warszawa 2017.

Hadyniak B., Ubezpieczenie jako urzqdzenie finansowe, [w:] Ubezpieczenia. Podręcznik akademicki, Handschke J., Monkiewicz J. [red.], Poltext, Warszawa 2010.

Kopaczyńska-Pieczniak K., Komentarz do art. 7096, [w:] Kodeks cywilny. Komentarz. Tom 3. Zobowiqzania - część szczególna, Kidyba A. [red.], LEX 2014.

Kowalewski E., Wprowadzenie do teorii interesu ubezpieczeniowego, [w:] Ubezpieczenia w gospodarce rynkowej. Tom 3, Wąsiewicz A. [red.], Oficyna Wydawnicza Branta, Bydgoszcz 1997. Kowalewski E., Reforma polskiego prawa ubezpieczeń gospodarczych w latach 1990-2001, [w:] Ubezpieczenia w gospodarce rynkowej. Tom 4, Sangowski T. [red.], Oficyna Wydawnicza Branta, Bydgoszcz-Poznań 2002.

Krywan T., Leasing samochodów osobowych, Publikacje Elektroniczne ABC.

Kubiak A. M., Interes ubezpieczeniowy w umowie ubezpieczenia na cudzy rachunek i na rzecz osoby trzeciej, „Prawo Asekuracyjne” 2012, nr 4.

Kucharski B., Przeniesienie praw z umowy ubezpieczenia, Wolters Kluwer, Warszawa 2010. Łazowski J., Wstęp do nauki o ubezpieczeniach, Wydawnictwo Prawnicze LEX, Sopot 1998.

Łopuski J., Komentarz do art. 808, [w:] Kodeks cywilny z komentarzem. Tom 2, Winiarz J. [red.], Wydawnictwo Prawnicze, Warszawa 1989.

Machnikowski P., Komentarz do art. 393, [w:] Kodeks cywilny. Komentarz, Gniewek E., Machnikowski P. [red.], CH Beck, Warszawa 2016.

Malinowska K., Umowa ubezpieczenia w Europie bez granic, Oficyna Wydawnicza Branta, BydgoszczWarszawa 2008.

Malinowska K., Komentarz do art. 821, [w:] Prawo ubezpieczeń gospodarczych. Komentarz. Tom II. Prawo o kontraktach w ubezpieczeniach. Komentarz do przepisów i wybranych wzorców umów, Brodecki Z., Glicz M., Serwach M. [red.], Wolters Kluwer, Warszawa 2010.

Maśniak D., Interes ubezpieczeniowy, niepub.

Mogilski W.W., Umowa ubezpieczenia na rzecz osoby trzeciej, [w:] Ubezpieczenia w gospodarce rynkowej. Tom 1, Wasiewicz A. [red.], Oficyna Wydawnicza Branta, Bydgoszcz 1994.

Nazaruk P., Komentarz do art. 7096, [w:] Kodeks cywilny. Komentarz, Ciszewski J. [red.], LexisNexis, Warszawa 2014. 
Orlicki M., Projektowane zmiany w regulacji materialnoprawnej umowy ubezpieczenia, [w:] Umowa ubezpieczenia. Aktualne problemy prawne. Materiały z konferencji naukowej „Problemy nowelizacji przepisów o umowie ubezpieczenia" z dnia 2 marca 2005 r., Koch A. [red.], Oficyna Wydawnicza Branta, Bydgoszcz-Poznań 2005.

Orlicki M, Strony umowy ubezpieczenia i podmioty zwiqzane ze stosunkiem prawnym ubezpieczenia, [w:] System prawa prywatnego. Prawo zobowiqzań - część szczegółowa. Tom 8, Panowicz-Lipska J. [red.], CH Beck, Warszawa 2011.

Pannert M., Wpływ upadłości likwidacyjnej na wykonywanie zobowiqzań z umów wzajemnych, Wolters Kluwer, Warszawa 2010.

Pinker G., Interes ubezpieczeniowy w ubezpieczeniach morskich na rynku angielskim, „Prawo Asekuracyjne" 1999, nr 2.

Pokrzywniak J., Komentarz do art. 808, [w:] Orlicki M., Pokrzywniak J., Umowa ubezpieczenia. Komentarz do nowelizacji kodeksu cywilnego, Wolters Kluwer, Warszawa 2008.

Stefanicki R., Interes ubezpieczeniowy w świetle art. 821 Kodeksu cywilnego, [w:] Kierunki rozwoju ubezpieczeń gospodarczych w Polsce. Wybrane zagadnienia prawne, Gnela B., Szaraniec M., Difin, Warszawa 2013.

Szymański Z., Ogólna charakterystyka ubezpieczenia od odpowiedzialności cywilnej, „Wiadomości Ubezpieczeniowe" 1964, nr 2.

Wạsiewicz A., Z rozważań nad funkcjonowaniem przepisów kodeksu cywilnego normujacych umowę ubezpieczenia, [w:] Rozprawy z prawa cywilnego: księga pamiq̨tkowa ku czci Witolda Czachórskiego, Rajski J. [red.], PWN, Warszawa 1985.

Wąsiewicz A., Kowalewski E., Postulowany kształt umowy ubezpieczenia w kodeksie cywilnym, „Państwo i Prawo” 1993, z. 11-12.

\section{Insurance contract for the subject of the lease as a contract for someone else's account}

In the last few years the economic significance of the lease agreement has also had an impact on the insurance services market, which is why the subject of the analysis in this article is the construction of the lease insurance contract as a contract for someone else's account. This particular form of insurance contract has become, in principle, an inseparable element accompanying the leasing contract. Bearing in mind the legal structure of the leasing contract, as well as the scope and nature of the insurance contract, the practical problems associated with providing effective insurance protection for the subject of the lease were given.

Keywords: leasing, insurance for someone else's account, insurance interest, insurance contract, beneficiary, financing.

DR ANNA PATALON-JURCZYK - Główny Specjalista w Departamencie Ubezpieczeń na Życie Sopockiego Towarzystwa Ubezpieczeń na Życie ERGO Hestia SA.

Artykuł przedstawia osobiste poglądy autorki, które nie mogą być utożsamiane ze stanowiskiem STUnŻ ERGO Hestia SA. 